Rev. Bras. Saúde Prod. Anim., Salvador, v.19, n.2, p.207-215 abr./jun., 2018

\title{
Effect of the climatic environment on ingestive behavior of F1 Holstein $x$ Zebu cows
}

\author{
Efeito do ambiente climático sobre o comportamento ingestivo de vacas F1 Holandês $x$ \\ Zebu
}

\author{
PEREIRA, Kátia Cristiane Borges ${ }^{1}$; CARVALHO, Cinara da Cunha Siqueira ${ }^{1 *}$; RUAS, \\ José Reinaldo Mendes ${ }^{1}$; MENEZES, Gustavo Chamon de Castro ${ }^{1}$; CASTRO, Anna \\ Luísa de Oliveira ${ }^{1}$, COSTA, Maria Dulcinéia $d^{1}$
}

${ }^{1}$ Universidade Estadual de Montes Claros, Departamento de Ciências Agrárias, Janaúba, Minas Gerais, Brasil.
*Endereço para correspondência: cinarasiqueira@yahoo.com.br

\section{SUMMARY}

The objective of this study was to evaluate the ingestive behavior of five different genetic groups of F1 Holstein $x$ Zebu (HxZ) cows during lactation during the summer. The evaluated groups were: Holstein x Gir, Holstein x Nelogir, Holstein $\mathrm{x}$ Guzonel, Holstein x Nelore and $\mathrm{x}$ Indubrasil. The experiment it occurred place during the summer in the Farm of Agricultural Research Company of Minas Gerais, located in FelixlândiaMG. A completely randomized design with factorial arrangement $5 \times 4$, five crossings and four periods of observation, with ten repetitions was used. The measurements of climate variables were made using dataloggers and calculated the black globe temperature and humidity index. There was the percentage of animals grazing, rumination, urination, defecation, water intake and salt intake during the day and at night every 30 minutes. The F1 animals used did not affect the grazing behavior due to high BGT values. There was a higher frequency of rumination and idle period in the morning, showing a natural behavior of cattle. Defecation was higher during the day, coinciding with the period of greater movement of animals. Water consumption was greater in the postmilking and the salt consumption in the afternoon. There was a positive statistical correlation between BGT and grazing, and negative correlation between BGT and leisure. Thus, the F1 animals grazing behavior has not changed because of the high BGT values, explaining the adaptability and resilience of five genetic groups, being a viable option for warm climate regions.

Keywords: ambience, behavior, dairy cattle
RESUMO

Objetivou-se avaliar o comportamento ingestivo de cinco diferentes grupos genéticos de vacas F1 Holândes x Zebu (HxZ), em lactação durante o verão. Os grupamentos avaliados foram: Holandês x Gir, Holandês x Nelogir, Holandês x Guzonel, Holandês x Nelore e Holandês x Indubrasil. O experimento ocorreu durante o verão na Fazenda da Empresa de Pesquisa Agropecuária de Minas Gerais, localizada na cidade de Felixlândia-MG. Utilizou-se delineamento experimental inteiramente casualizado, com arranjo fatorial $5 \mathrm{x}$ 4 , sendo cinco cruzamentos e quatro períodos de observação, com dez repetições. As medições das variáveis climáticas foram feitas com o uso de dataloggers e calculou-se o Índice de temperatura globo negro e umidade (ITGU). Observou-se à porcentagem de animais em pastejo, ruminação, ócio, micção, defecação, ingestão de água e consumo de sal no período diurno e noturno a cada 30 minutos. Os animais F1 utilizados não alteraram o comportamento de pastejo devido aos altos valores de ITGU. Houve maior frequência de ruminação e ócio no período da madrugada. A defecação foi maior no período diurno, coincidindo com o período de maior movimentação dos animais. O consumo de água foi maior no pós ordenha e o consumo de sal no período da tarde. Houve correlação estatística positiva entre ITGU e pastejo, e correlação negativa entre ITGU e ócio. Assim, o comportamento de pastejo dos animais F1 não foi alterado em virtude dos elevados valores de ITGU, explicitando a adaptabilidade e resistência dos cinco grupos genéticos a altas temperaturas, sendo uma opção viável para regiões de clima quente.

Palavras-chave: ambiência, bovinos leiteiros, comportamento 


\section{INTRODUCTION}

The tropical climate covers a wide area of the Brazilian territory, in this context the use of F1crossbred HxZ animals is based on taking advantage of zebu resistance to heat stress and other environmental stressors that may limit the expression of productive characteristics in tropical and subtropical areas (BÓ et al., 2003). From the heterosis it is possible to obtain animals with efficiency in the loss of heat by sweating, due to the greater number and volume of sweat glands, besides shorter pelage, presence of dewlap and abundant skin (PEREIRA et al., 2008; ARTMANN et al. al., 2014).

Thus, it is possible to obtain milk at a low cost, since crossbreeding allows maximizing the use of heterosis effect and complementarity between breeds (McMANUS et al., 2008).

During feeding of grazing cattle, their main activities are divided between the grazing period, rumination and leisure, and the time spent to each one depends on the characteristics of the pasture, climatic conditions and nutritional requirements of the animal (ZANINE et al., 2007). However, under stress conditions, the animals tend to decrease grazing and exercise during the day, besides reducing food intake, increasing water intake and consequently reducing productivity (CARLOTTO et al., 2007). Nevertheless, it is imperative to know the behavior of F1 animals exposed to different climatic conditions in order to verify differences and / or similarities with pure animals. And thus, to allow the use of zootechnical techniques in periods unfavorable to the consumption of nutrients, in order to minimize the environmental effects and ensure the animal production at high level.

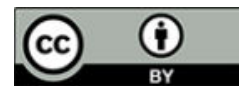

In that sense, we aimed to evaluate the ingestive behavior of different genetic groups of $\mathrm{F} 1$ Holstein $\mathrm{x}$ Zebu cows during the lactation phase in summer.

\section{MATERIAL AND METHODS}

The experiment was conducted during the summer (February to April 2015) at the Agricultural Research Company of Minas Gerais (EPAMIG), located in the municipality of Felixlândia, Minas Gerais, with a maximum annual average temperature of $29.7^{\circ} \mathrm{C}$ and a minimum of $16.6{ }^{\circ} \mathrm{C}$. The climate is classified, according to Köppen, as savanna tropical, with two distinct seasons, the dry winter and the rainy summer. The average annual precipitation is 1,126 $\mathrm{mm}$.

The project was evaluated and approved by the Committee of Ethics in Animal Experimentation and Welfare of the State University of Montes Claros (UNIMONTES) - process n. 084/2015.

For the analysis of the genetic groups, we used the completely randomized design (CRD), in the factorial scheme 5 treatments (genetic groups) and 20 repetitions (schedules). The animals were from crosses containing as a genetic base a Holstein bull and zebu cows that belonged to 5 genetic groups, totalizing $21 \mathrm{~F} 1$ cows in the lactation period, being: 5 F1 animals: Holstein $(50 \%) \times$ Gir $(50 \%), 5$ animals $\mathrm{F} 1$ : Holstein (50\%) x Nelogir (50\%), 3 animals F1: Holstein (50\%) x Guzonel $(50 \%)$ and 4 animals F1: Holstein $(50 \%) \times$ Indubrasil (50\%). The Table 1 shows the physical and productive characterization of the studied lot. 
Table 1. Characterization of the evaluated genetic groups

\begin{tabular}{lccccc}
\hline $\begin{array}{l}\text { Genetic } \\
\text { Groupings }\end{array}$ & Age (years) & Weight $(\mathrm{kg})$ & Number of Births & Lactation stage & Milk Production $(\mathrm{kg})$ \\
\hline H x Gir & 7,2 & 490,0 & 3,7 & 320 & 3728,0 \\
H x Nelogir & 7,0 & 502,0 & 4,6 & 331 & 3624,1 \\
H x Guzonel & 4,3 & 501,0 & 2,0 & 270 & 2106,3 \\
H x Nelore & 5,0 & 531,0 & 2,6 & 244 & 2093,6 \\
H x Indubrasil* & 8,0 & 504,2 & 4,0 & 240 & 2010,2 \\
\hline
\end{tabular}

*Composed of $100 \%$ zebuine with Indubrasil prevalence.

The 21 animals were kept together in rotated pickets of Urochloa brizantha, with an area of 1 hectare each, with rotation every 2 days, totalizing 7 pickets. The pasture presented average forage availability around 18.58 tons of natural matter per hectare and $24 \%$ of DM (dry matter). During the experiment the cows had access to pasture with mineral salt supplementation in the trough and water ad libitum; while in the milking period in the morning and in the afternoon they received commercial crowded meal for dairy cattle.

Measurements of ambient temperature and black globe $\left({ }^{\circ} \mathrm{C}\right)$ and relative air humidity $(\%)$ were performed using the continuous reading datalogger (RHT 10 model, Instrutemp, Brazil), programmed to collect every 10 minutes. These data were calculated using the GlobeTemperature-Humidity-Index (GTHI) proposed by Buffington et al. (1981), obtained after expression.

$$
\mathrm{GTHI}=\mathrm{Bgt}+0.36 \times \mathrm{Tpo}+41.5 \text { eq. } 1
$$

Where:

$\mathrm{DPT}=$ Dew point temperature $\left({ }^{\circ} \mathrm{C}\right)$

Bgt $=$ Black globe temperature $\left({ }^{\circ} \mathrm{C}\right)$

The behavioral analysis occurred after 7 days of adaptation, when the observers remained in the pasture in direct contact with the animals, walking and approaching them until they became accustomed to the human presence, including the use of the lantern at night to desensitize the cattle to the use of artificial light.

Data collection lasted 10 days using the Scan Sampling method (ALTMANN, 1974). This was a direct and representative observation of the behavioral reality of the animals, so that the percentage animals as for grazing, rumination, leisure, urination, defecation, water intake and salt consumption during the day and night were observed every 30 minutes for 10 days. However, observations as for urination, water consumption and salt, which are behaviors occurring infrequently may be underestimated.

During that period the observation was always carried out by two groups composed of two observers each one, who did the relay every 24 hours. They walked among the animals looking at and noting the behavior of the animals, witn flashlight aid at night. Observations began at 09:00 p.m., after returning from milking at 7:00 p.m. and continued until 01:00 p.m., when the animals were removed from the pasture for afternoon milking at 2:00 p.m., returning at 3:00 p.m., when observations continued until 5:00 a.m. To better evaluate the effect of the behavior, collection times were grouped into 4 periods: morning: 09:00 a.m. to 12:00, afternoon: 01:00 to 06:00 p.m, night: 7:00 p.m. to $00: 00$ and in the morning: 01:00 a.m. to 05:00 a.m. 
For the analysis of the genetic groups, the experimental design was completely randomized (CRD), in the $5 \times 4$ factorial scheme, being 5 genetic groups and 4 periods. Analysis of variance was used to evaluate the schedules and periods. The used statistical model was:

$$
Y i j=\mu+G_{i}+P_{j}+G_{i} P_{j}+\varepsilon_{i j}
$$

Where: Yijk is the observed dependent variable for each animal group " $i "$, in period "j"; $\mu$ is the overall mean; Gi is the effect of animals groups "i"; $\mathrm{Pj}$ is the effect of periods " $\mathrm{j}$; $\mathrm{Gi} \mathrm{Pj}$ is the interaction of groups and periods; $\varepsilon \mathrm{ij}$ is the random error.

As there was no effect of the genetic group, a second analysis was performed eliminating the statistical model. After analysis of variance, the means of the periods were compared by the Scott Knott test $(\mathrm{P}<0.05)$. The SNK StudentNewman-Keuls test $(\mathrm{P}<0.05)$ was used to analyze the periods and variables and climatic indexes.
The processing of the analyzes adopted the procedures of the Software of Statistical Analysis System (SAEG 9.1).

\section{RESULTS AND DISCUSSION}

In Table 2 it can be observed that in the morning and afternoon periods $(\mathrm{P}>0.05)$, the air temperature averages presented high values, out of the range recommended for zebuines of 10 to $27^{\circ} \mathrm{C}$ (FURTADO et al., 2012). Relative humidity was below 40\%; however, in the night and in dawn periods $(\mathrm{P}>0.05)$, the mean was higher than $70 \%$; however, in the literature, the relative humidity is recommended between 40 and $70 \%$ for most of the domestic species (NÄ̈̈S and ARCARO JÚNIOR, 2011). In these same periods, the GTHI presented values compatible with the thermal comfort recommendation proposed by Buffington et al. (1981) for dairy cattle (Table 2), maintaining values above 74 in the other periods.

Table 2. Average values of air temperature (Tar), Relative Humidity (RH), Black Globe Temperature (BGT) and Globe-Temperature-Humidity-Index (GTHI) in function of evaluated periods

\begin{tabular}{lcccccccc}
\hline Period & Tar $\left({ }^{\circ} \mathrm{C}\right)$ & S.D. & RH $(\%)$ & S.D. & Bgt $\left({ }^{\circ} \mathrm{C}\right)$ & S.D. & GTHI & S.D. \\
\hline Morning & $33,8^{\mathrm{a}}$ & $\pm 3,2$ & $51,6^{\mathrm{a}}$ & $\pm 8,5$ & $31,6^{\mathrm{a}}$ & $\pm 3,2$ & $82,0^{\mathrm{a}}$ & $\pm 1,6$ \\
Afternoon & $33,5^{\mathrm{a}}$ & $\pm 3,7$ & $52,4^{\mathrm{a}}$ & $\pm 8,2$ & $30,8^{\mathrm{b}}$ & $\pm 3,5$ & $80,0^{\mathrm{a}}$ & $\pm 3,5$ \\
Night & $22,4^{\mathrm{b}}$ & $\pm 1,1$ & $91,8^{\mathrm{b}}$ & $\pm 4,6$ & $24,5^{\mathrm{c}}$ & $\pm 1,3$ & $73,7^{\mathrm{b}}$ & $\pm 1,7$ \\
Dawn & $20,2^{\mathrm{b}}$ & $\pm 0,3$ & $97,7^{\mathrm{b}}$ & $\pm 0,6$ & $21,1^{\mathrm{d}}$ & $\pm 0,5$ & $69,0^{\mathrm{c}}$ & $\pm 0,5$ \\
\hline V.C. & 8,9 & - & 9,8 & - & 8,5 & - & 2,7 & - \\
\hline
\end{tabular}

Means followed by different letters in the column differ from each other by the SNK test $(\mathrm{P}<0.05)$

The climatic parameters presented in Table 2 show the natural records verified during the summer, when there is a predominance of high temperatures during the day and the incidence of higher solar radiation with fluctuations of rainy periods mainly at night and dawn.
The percentage of grazing animals was different $(\mathrm{P}<0.05)$ in the four evaluated periods, with the highest number of animals $(56.7 \%)$ followed by the morning $(44.4 \%)$, at night $(36.6 \%)$ and dawn $(6.7 \%)$. This fact evidences the adaptation of the crossbred animals due to rusticity 
conferred by the heterosis of the HxZ. In Figure 1 it is possible to visualize the grazing peaks that were similar to the study carried out by Carlotto et al. (2007), which evaluated the behavior of Holstein cows, verified a similar result of grazing after the milking of the morning (09:00 a.m.) and in the afternoon (01:00 to 03:00 p.m).

Thus, it is possible to emphasize that the grazing of crossbred cows was not affected by the climatic environment, since in the morning and afternoon the highest GTHI values were recorded (Table 3).

This behavior is desirable and expected due to the rusticity and adaptability of the F1 animals, demonstrating that even when exposed to unfavorable climatic conditions, they do not stop feeding and consequently do not reduce production. Artmann et al. (2014) emphasize that the heat resistance of crossbred animals is characterized by the number of sweat glands, which are larger and more efficient in sweating, which prevents endogenous heat storage.

According to the data presented in Table 3 , there was a higher percentage of animals $(\mathrm{P}<0.05)$ in rumination during dawn $(42.2 \%)$, followed by the nocturnal period with rumination peaks at 7:00 p.m. $(48.9 \%)$ and at 8: 00 p.m. (41.6\%) (Figure 1).

According to Costa and Silva et al. (2010), cattle under heat stress tend to reduce rumination time and increase leisure, in an attempt to reestablish their thermal equilibrium. However, the lowest rumination values observed in the morning $(26.9 \%)$ and in the afternoon $(18.9 \%)$ are not related to thermal stress, since there was no substitution of rumination for leisure (Table 3). Thus, the low values of rumination in these periods occurred due to the preference of animals for grazing, demonstrating that, even with high GTHI, F1 animals of the experiment remained with their normal activities, without behavioral changes caused by thermal stress.

In the times with higher GTHI values, morning (82.0) and afternoon (80.0), there was not predominance of leisure $(\mathrm{P}$ $<0.05)$ nor grazing replacement for another activity (Table 3), demonstrating that the animals were not in thermal discomfort. At 05:00 a.m., the percentage of animals in leisure reached $58.8 \%$ and this percentage reached $32.8 \%$ of animals in leisure at 7:00 p. m. (Figure 1). The highest percentages of leisure occurred during the dawn (48.9\%), followed by the night $(23.7 \%)$, and no behavioral changes were observed to minimize a possible thermal stress effect (Table 3). In addition, considering the occurrence of grazing peaks in the afternoon and morning, during the dawn, the animals were in leisure to metabolize the food consumed throughout the day, while at the same time they rest before the first milking of the day. Therefore, it is noted that, during the experiment, there was no negative influence of the GTHI on leisure activity.

The lowest percentages of animals in leisure were observed in the morning $(15.6 \%)$, followed by the afternoon (11.5\%), expressing that F1 HxZ animals do not were in leisure due to high temperatures.

Water consumption was higher in the morning (9.2\%) and afternoon (8.2\%), without any statistical difference between both ( $>>$ 0.05) (Table 3), with consumption peaks at 09:00 a.m. and 03:00 p.m. (Figure 1). In periods of higher water consumption, the highest GTHI values were observed (Table 3), so that, with time, there was a decrease in GTHI values and also in water consumption, reaching $2.9 \%$ at night and $0.8 \%$ at dawn. 
Table 3. Averages values for the percentage of animals as grazing, rumination, leisure, water consumption, urination, defecation and salt consumption during the studied periods

\begin{tabular}{|c|c|c|c|c|c|c|c|c|c|c|c|c|c|c|c|c|}
\hline Periods & GRAZ & S.D & RUM & S.D & LEIS & S.D & WATER & S.D & URI & S.D. & DEF & S.D. & SAL & S.D. & GTHI & S.D. \\
\hline Morning & $44,4^{b}$ & $\pm 34,1$ & $26,9^{c}$ & $\pm 28,2$ & $15,6^{\mathrm{c}}$ & $\pm 22,0$ & $9,2^{\mathrm{a}}$ & $\pm 5,2$ & $1,0^{\mathrm{a}}$ & $\pm 7,1$ & $1,6^{\mathrm{a}}$ & $\pm 16,2$ & $0,9^{\mathrm{b}}$ & $\pm 4,8$ & $82,0^{\mathrm{a}}$ & $\pm 1,6$ \\
\hline Afternoon & $56,5^{\mathrm{a}}$ & $\pm 33,4$ & $18,9^{\mathrm{d}}$ & $\pm 26,0$ & $11,5^{\mathrm{d}}$ & $\pm 19,6$ & $8,2^{\mathrm{a}}$ & $\pm 4,7$ & $0,9^{\mathrm{a}}$ & $\pm 6,1$ & $1,4^{\mathrm{a}}$ & $\pm 14,9$ & $2,1^{\mathrm{a}}$ & $\pm 7,2$ & $80,0^{\mathrm{a}}$ & $\pm 3,5$ \\
\hline Night & $36,6^{\mathrm{c}}$ & $\pm 27,9$ & $34,8^{\mathrm{b}}$ & $\pm 28,1$ & $23,7^{\mathrm{b}}$ & $\pm 24,5$ & $2,9^{\mathrm{b}}$ & $\pm 5,4$ & $0,7^{\mathrm{a}}$ & $\pm 4,1$ & $0,6^{\mathrm{b}}$ & $\pm 8,9$ & $0,4^{\mathrm{b}}$ & $\pm 3,3$ & $73,7^{\mathrm{b}}$ & $\pm 0,7$ \\
\hline Dawn & $6,7^{\mathrm{d}}$ & $\pm 14,1$ & $42,2^{\mathrm{a}}$ & $\pm 25,5$ & $48,8^{\mathrm{a}}$ & $\pm 27,4$ & $0,8^{\mathrm{c}}$ & $\pm 4,3$ & $0,5^{\mathrm{a}}$ & $\pm 2,9$ & $0,3^{\mathrm{b}}$ & $\pm 4,5$ & $0,2^{\mathrm{b}}$ & $\pm 2,1$ & $69,0^{\mathrm{c}}$ & $\pm 0,5$ \\
\hline V.C. & \multicolumn{2}{|c|}{68,1} & \multicolumn{2}{|c|}{70,8} & \multicolumn{2}{|c|}{80,6} & \multicolumn{2}{|c|}{234,3} & \multicolumn{2}{|c|}{618,0} & \multicolumn{2}{|c|}{561,8} & \multicolumn{2}{|c|}{533,4} & \multicolumn{2}{|c|}{2,7} \\
\hline Value of $\mathrm{P}$ & \multicolumn{2}{|c|}{0,00015} & \multicolumn{2}{|c|}{0,00014} & \multicolumn{2}{|c|}{0,00014} & \multicolumn{2}{|c|}{0,00014} & \multicolumn{2}{|c|}{0,32496} & \multicolumn{2}{|c|}{0,00103} & \multicolumn{2}{|c|}{0,00014} & \multicolumn{2}{|c|}{0,00010} \\
\hline
\end{tabular}

Means followed by different letters in the column differ from each other by the SNK test $(\mathrm{P}<0.05)$.
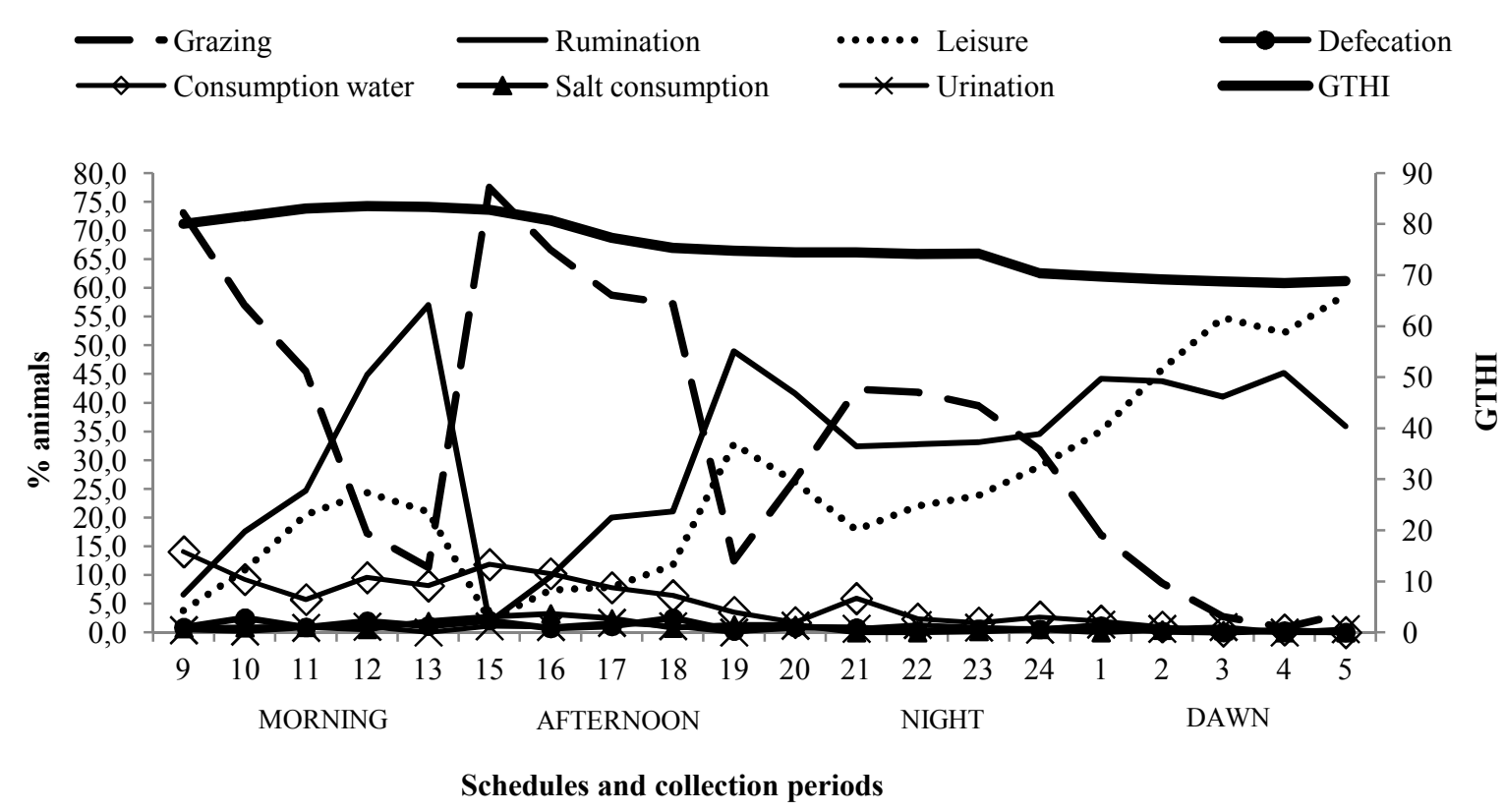

Figure 1. Mean values in percentages of the behavior of the animals according to the evaluated schedules and the GTHI 
The water consumption during periods of higher GTHI values did not show inversion in food intake (Figure 1), indicating that water consumption occurred in a normal way, taking into account the physiological needs of the animals. During the day, the greater movement for grazing, and the occurrence of milking may be the factors responsible for the greater consumption of water (Table 3). Thus, even with the highest percentage of animals consuming water in the daytime period, the animals presented a uniform distribution of urination $(\mathrm{P}>0.05)$, showing that there was no climatic interference on this behavior. The highest percentages of defecating animals were observed in the daytime period $(1.5 \%)$ (Table 3 ), with peaks at 10:00 a.m. (2.5\%), after the arrival of the animals in the pasture, and at $12: 00(2.0 \%)$ (Figure 1), the time before milking, when the mostly animals were in rest areas. During the night and dawn, when the animals remained in leisure, the lowest percentages of defecating animals were found without statistical differences between the periods.

The highest percentage of animals consuming salt occurred in the afternoon (2.2\%), between 01:00 p.m. and 05:00 p.m., coinciding with the period of highest percentage of grazing animals.

The higher salt intake during the afternoon is justified by the greater movement of the animals in the pasture for the consumption of fodder and water. Compared with the nocturnal period, when the animals remain in a longer resting, there is a decrease in the percentage of animals consuming salt, being the morning $(0.9 \%)$, night $(0.4 \%)$ and dawn $(0.2 \%)$, without significant differences between them.

There was a statistically significant correlation for all analyzed variables. However, correlation between rumination $(*-0.285)$, water consumption $(* 0.284)$, urination $(* 0.049)$ and defecation $(*$ 0.091) was considered very weak, i.e., the climate did not have representative influence on these behaviors (Table 4).

Table 4. Statistical correlation between the analyzed behavioral variables and the Globe Temperature-Humidity-Index (GTHI)

\begin{tabular}{lc}
\hline Variable & CORRELATION \\
\hline Grazing & $0,486^{* *}$ \\
Rumination & $-0,285^{* *}$ \\
Leisure & $-0,473^{* *}$ \\
Urination & $0,049^{* *}$ \\
Defection & $0,091^{* *}$ \\
Water & $0,284^{* *}$ \\
Salt & $0,119^{* *}$ \\
\hline$* *$ Significant values of correlation $(\mathrm{P}<0,05)$. & \\
\hline
\end{tabular}

The grazing behavior showed a significant correlation, but moderate, indicating that the increase in the GTHI values influenced the increase of the percentage of grazing animals, i.e., at the times of the highest GTHI, it was also possible to verify a high percentage of grazing animals. For the leisure behavior, there was a negative correlation, showing a moderate influence between the elevation of GTHI values and the decrease of the 
percentage of animals in leisure. In this sense, the higher the GTHI values, the lower were the percentages of animals in leisure.

The five crosses of F1 HxZ cows under study did not alter ingestive behavior in the presence of the climatic environment, even with GTHI reaching an average value of 83.6, demonstrating that they have resistance to high temperatures and a viable option for hot climate regions.

\section{ACKNOWLEDGEMENTS}

A FAPEMIG, CAPES, CNPq, EPAMIG, UNIMONTES, FINEP e MCTI financial support for the project $n^{\circ} 1334 / 13$.

\section{REFERENCES}

ALTMANN, J. Observational study of behavior: Sampling methods.

Behaviour, v.48, n.3-4, p.227-267, 1974.

ARTMANN, T.A.; TOMA, H.S.; PINHEIRO, J.N.; ROMERO, J.; CARVALHO, A.M.; MONTEIRO TOMA, C.D. Melhoramento genético de bovinos $1 / 2$ sangue taurino $\mathrm{x} 1 / 2$ sangue zebuíno no Brasil. Revista Científica Eletrônica de Medicina Veterinária, v.22, n.1, p.1-20, 2014.

BÓ, G.A.; BARUSELLI, P.S.; MARTINEZ, M.F. Pattern and manipulation of follicular development in Bosindicus cattle. Animal Reproduction Science, v.78, n.3-4, p.307-326, 2003.
BUFFINGTON, D.E.; COLLAZOAROCHO, A.; CANTON, G.H.; PITT, D.; THATCHER, W.W.; COLLIER, R.J. Black globe humidity index (BGHI) as a comfort equation for dairy cows. Transactions ASAE, v.24, n.3, p.711-714, 1981.

CARLOTTO, S.B.; OLIVO, C.J.; VIÉGAS, J.; STILES, D.A.; GABBI, A.M.; BRUSTOLIN, K.D.; CHARÃO, P.S.; ROSSAROLLA, G.; ZIECH, M.; PEREIRA, L.E.T.; SCARAVELLI, L.F. Performance and behavior of dairy calves fed diets containing milk and citric flavor agents. Ciência e Agrotecnologia, v.31, n.3, p.889-895, 2007.

COSTA e SILVA, E.V.; KATAYAMA, K.A.; MACEDO, G.G.; RUEDA, P.M.; ABREU, U.G.P.; ZÚCCARI, C.E.S.N. Efeito do manejo e de variáveis bioclimáticas sobre a taxa de gestação em vacas receptoras de embriões.

Ciência Animal Brasileira, v.11, n.2, p.280-291, 2010.

FURTADO, D.A.; PEIXOTO, A.P.; REGIS, J.E.F.; NASCIMENTO, J.W.B.; ARAUUJO, T.G.P.; LISBOA, A.C.C. Termorregulação e desempenho de tourinhos Sindi e Guzerá, no agreste paraibano. Revista Brasileira de Engenharia Agrícola e Ambiental, v.16, n.9, p.1022-1028, 2012.

McMANUS, C.; TEIXEIRA, R. de A.; DIAS, L.T.; LOUVANDINI, H.; OLIVEIRA, E.M.B. Características produtivas e reprodutivas de vacas Holandesas e mestiças Holandês $\times$ Gir no Planalto Central. Revista Brasileira de Zootecnia, v.37, n.5, p.819-823, 2008. 
MARTIN, P.; BATESON, P.

Measuring behaviour: an introductory guide. 2.ed. Cambridge: Cambridge University Press, 1993.

MORAIS, D.A.E.F.; MAIA, A.S.C.; SILVA, R.G.; VASCONCELOS, M.A.; LIMA, O.P.; GUILHERMINO, M.M. Variação anual de hormônios tireoideanos e características termorreguladoras de vacas leiteiras em ambiente quente. Revista Brasileira de Zootecnia, v.37, n.3, p.538-545, 2008.

NÄÄS, I.A.; ARCARO JÚNIOR, I. Influencia de ventilação e aspersão em sistemas de sombreamento artificial para vacas em lactação em condições de calor. Revista Brasileira de Engenharia Agrícola e Ambiental, v.5, n.1, p.139-142, 2001.

PEREIRA, J.C.; CUNHA, D.N.F.V.; CECON, P.R.; FARIA, E. de S. Desempenho, temperatura retal frequência respiratória de novilhas leiteiras de três grupos genéticos recebendo dietas com diferentes níveis de fibra. Revista Brasileira de Zootecnia, v.37, n.2, p.328-334, 2008.

TAVARES, J.E.; BENEDETTI, E. Uso de bebedouros e sua influência na produção de bovinos em pasto. FAZU em Revista, v.8, p.152-157, 2011.

ZANINE, A.M.; VIEIRA, B.R.; FERREIRA, D.J. Comportamento ingestivo de bovinos de diferentes categorias em pastagem de capim Coastcross. Bioscience Journal, v.23, n.3, p.111-119, 2007.
ZANINE, A.M.; VIEIRA, B.R.; FERREIRA, D.J; VIEIRA, M.J.A.; LANA, P.R.; CECON, R.P.

Comportamento ingestivo de diversas categorias de bovinos da raça Girolanda, em pasto de Brachiaria Brizantha cv. Marandu. Arquivos de Ciências Veterinárias e Zoologia da Unipar, v.11, n.1, p.35-40, 2008.

Receipt date: 07/02/2017 Approval date: 06/03/2018 